\title{
ОСОБЛИВОСТІ ФУНКЦІОНУВАННЯ СЕРЦЕВО-СУДИННОї СИСТЕМИ У ХВОРИХ НА СИНДРОМ ОБСТРУКТИВНОГО АПНОЕ-ГІПОПНОЕ У НІЧНИЙ ЧАС
}

\section{Тернопільський національний медичний університет імені І. Я. Горбачевського МОз України}

РЕзюМЕ. У статті наведені результати досліджень особливостей функціонування серцево-судинної системи у хворих на синдром обструктивного апное-гіпопное сну.

Мета - оцінити особливості функціонування серцево-судинної системи у хворих на синдром обструктивного апное-гіпопное під час сну.

Матеріал і методи. Дослідження проведено у 66 хворих із діагностованим синдромом обструктивного апное-гіпопное сну (СОАГС). Діагноз СОАГС встановлювали у пацієнтів, в яких протягом 1 години сну виявляли понад 5 зупинок дихання тривалістю 10 секунд та більше (індекс апное-гіпопное, ІАГ).

Результати. Встановлено, що в нічний час під час епізодів апное-гіпопное синхронно тяжкості патології розвивається феномен активації серцево-судинної системи, який проявляється зростанням серцевого викиду, частоти серцевих скорочень та загального периферійного судинного опору. Під час сну коефіцієнт економічності кровообігу (КЕК) у пацієнтів групи контролю знижувався майже на $40 \%$, порівняно з даними, отриманими в них удень. Однак, порівняно з групою контролю, уночі КЕК у хворих 1-ї групи виявився вищим на 11,4 \%; у хворих 2-ї групи на 8,0 \%; у хворих 3-ї групи - на 25,8 \%.

Висновки. Активація серцево-судинної системи у хворих на СОАГС сприяє формуванню у них гіпертонічної хвороби, а зростання загального периферійного опору судин призводить до органних порушень (серцевої, ниркової недостатності, цукрового діабету тощо).

КЛючОВІ СлОВА: синдром обструктивного апное-гіпопное сну; системна гемодинаміка; серцевий викид; загальний периферійний судинний опір; коефіцієнт економічності кровообігу.

Вступ. Синдром обструктивного апное-гіпопное під час сну (СОАГС) - патологічний стан зупинки вентиляції легень понад 10 секунд; при цьому протягом 7-годинного сну апное-гіпопное реєструється не менше 30 разів [1]. Цей синдром зумовлений періодичною обструкцією верхніх дихальних шляхів на рівні горла; при цьому на фоні збереження дихальних зусиль призупиняється легенева вентиляція та знижується насиченість крові киснем; у пацієнтів виникають груба фрагментація сну та надмірна денна сонливість [2].

СОАГС має значну поширеність. Наприклад, у США на цю патологію страждає понад 12 мільйонів людей.

Мета - оцінити особливості функціонування серцево-судинної системи у хворих на СОАГС у нічний час.

Матеріал і методи дослідження. Дослідження проведено у 66 хворих із діагностованим синдромом обструктивного апное-гіпопное сну. Діагноз СОАГС встановлювали, якщо у пацієнтів виявляли протягом 1 години сну понад 5 зупинок дихання тривалістю 10 секунд та більше (індекс апное-гіпопное, ІАГ) [1].

За частотою порушень дихання уві сні провели поділ досліджуваних пацієнтів на групи: легкого, середньої тяжкості і тяжкого ступенів. Контрольну групу склали 20 осіб такого ж віку та маси тіла.

Моніторування показників гемодинаміки у нічний час хворим проводили під час детального полісомнографічного обстеження. Досліджували середні (баз.) показники системної гемодинаміки (ЧСС, АТсист., АТдіаст., САТ), серцевого викиду (УО, ХОС та їхні індекси), загального периферійного опору судин (ЗПОС), коефіцієнт економічності системи кровообігу (КЕК), індекс Робінсона (IP).

Результати й обговорення. Під час сну в усіх людей унаслідок зниження основного обміну знижується й частота серцевих скорочень. Зокрема, в осіб контрольної групи ЧСС знижувалась від $(76,0 \pm$ $2,0)$ уд:хв-1 (результати денних вимірювань) до $(58,0 \pm 1,2)$ уд $\times$ Хв$^{-1}$ (вночі), або на $23,6 \%$. Отримані результати вимірювань відповідають літературним даним [3] і зумовлені відсутністю активних рухів уночі, горизонтальним положенням тіла, в якому перебуває людина, та мінімальною потребою у діяльності серця у цей час для забезпечення зниженого енергетичного обміну в період «царювання вагуса».

Разом з тим, у досліджуваного контингенту хворих частота серцевих скорочень (середні ії значення) протягом ночі збільшувалась: від 9,0 до 16,8 уд.хв ${ }^{-1}$, або на $30 \%$, порівняно з пацієнтами, які спали вночі спокійно, без порушень дихання (табл. 1). Очевидно, причиною нічної тахікардії у хворих на СОАГС $\epsilon$ стимулювання симпатоадреналової активності, зумовлене нападами апноегіпопное уві сні.

При аналізі співвідношень між ЧСС удень та вночі у тих же самих осіб (циркадна динаміка сер- 
Огляди літератури, оригінальні дослідження, погляд на проблему, випадок з практики, короткі повідомлення Таблиця 1. Показники діяльності серцево-судинної системи у хворих на синдром обструктивного апное-гіпопное у нічний час $(\mathrm{M} \pm \mathrm{m})$

\begin{tabular}{|c|c|c|c|c|}
\hline \multirow{2}{*}{ Показник } & \multirow{2}{*}{$\begin{array}{c}\text { У осіб контрольної } \\
\text { групи }\end{array}$} & \multicolumn{3}{|c|}{ У хворих на СОАС різного ступеня тяжкості } \\
\hline & & легкого & середньої тяжкості & тяжкого \\
\hline ІАГ / год & $1,8 \pm 0,2$ & $6,6 \pm 0,2^{*}$ & $12,1 \pm 1,1 * *$ & $21,5 \pm 1,2 * *$ \\
\hline ЧССбаз. уд·хв. ${ }^{-1}$ & $58,0 \pm 1,2$ & $67,0 \pm 1,6 * *$ & $70,2 \pm 1,8^{* *}$ & $74,8 \pm 2,2 * *$ \\
\hline АТсист.баз., кПа & $14,9 \pm 0,3$ & $17,4 \pm 0,2 * *$ & $17,9 \pm 0,3 * *$ & $20,2 \pm 0,3 * *$ \\
\hline АТдіаст.баз., кПа & $9,3 \pm 0,2$ & $12,0 \pm 0,3$ ** & $12,9 \pm 0,2 * *$ & $14,5 \pm 0,2 * *$ \\
\hline САТбаз., кПа & $13,0 \pm 0,2$ & $13,8 \pm 0,3^{*}$ & $14,6 \pm 0,1 * *$ & $16,4 \pm 0,2 * *$ \\
\hline уобаз., мл & $90,8 \pm 1,8$ & $83,0 \pm 2,6 * *$ & $81,0 \pm 1,9 * *$ & $84,2 \pm 2,1$ ** \\
\hline УІбаз. мл·м-2 & $43,3 \pm 1,4$ & $39,5 \pm 2,2^{*}$ & $38,6 \pm 2,1 * *$ & $40,1 \pm 1,9 *$ \\
\hline ХОСбаз. л·ХВ ${ }^{-1}$ & $5,27 \pm 0,1$ & $5,56 \pm 0,2 * *$ & $5,69 \pm 0,2 * *$ & $6,30 \pm 0,17 * *$ \\
\hline СІ баз. л $\times \mathrm{XB}^{-1} \mathrm{M}^{-2}$ & $2,5 \pm 0,1$ & $2,65 \pm 0,2 * *$ & $2,71 \pm 0,1 * *$ & $3,00 \pm 0,2^{* *}$ \\
\hline KEK, y. o. & $2436,0 \pm 28,6$ & $2713,5 \pm 30,1$ & $2632,6 \pm 31,4$ & $3069,8 \pm 35,5$ \\
\hline IP & $64,8 \pm 1,2$ & $87,4 \pm 2,1$ & $94,2 \pm 2,3$ & $113,3 \pm 2,5$ \\
\hline ЗПОСбаз дин $\cdot \mathrm{c}^{-1} \cdot \mathrm{cm}^{-5}$ & $1480,1 \pm 21,6$ & $1489,2 \pm 24,8$ & $1539,5 \pm 32,2$ & $1561,7 \pm 37,1$ \\
\hline
\end{tabular}

Примітка: * - p<0,05; ** - p<0,01 у порівнянні з показниками у осіб групи контролю.

цевих скорочень) виявлені такі результати: в осіб контрольної групи - 131,0; при патології легкого ступеня - 119,3; при патології середнього - 118,1; при тяжкій патології - 115,2. Такі дані чітко вказують на те, що циркадна динаміка, порівняно з нормою, зміщується у ліву сторону, що, знову ж таки, характерно для підвищення активації симпатичної нервової системи саме вночі.

Ми виявили, що у хворих на СОАГС уночі при неспокійному сні достовірно зростають усі показники артеріального тиску: систолічного, діастолічного та середнього, порівняно з пацієнтами контрольної групи.

При цьому артеріальний тиск діастолічний (базальний) зростає на більш суттєву величину, порівняно з систолічним. У хворих 1-ї групи таке зростання становило 44 \% при АТсист. та $9 \%$ при АТдіаст;; у хворих 2-ї групи, відповідно, 55,4 \% та $12,5 \%$; у хворих $3-і ̈$ групи - 62,6 \% та 27,0 \%.

Виявили, що під час сну коефіцієнт економічності системи кровообігу у пацієнтів групи контролю знижувався майже на $40 \%$, порівняно з даними, отриманими в них удень. У більш економному режимі, порівняно із денними показниками, уночі функціонує система кровообігу й у обстежуваних хворих. Однак, порівняно з групою контролю, уночі КЕК у хворих 1-ї групи виявився вищим на 11,4 \%; у хворих 2-ї групи - на 8,0 \%; у хворих 3-ї групи - на 25,8\%.

Отримані результати дослідження вказують на те, що у хворих на СОАГС серцево-судинна система під час нічного сну працює у більш напруженому режимі, аніж це необхідно для повноцінного відпочинку організму.

Індекс Робінсона, який визначає навантаження серця для подолання потоку крові в артеріаль- ному руслі, виявився найбільш інформативним: у осіб групи котролю він становив $64,8 \pm 1,2 ;$ у хворих із захворюванням легкого ступеня $-87,4 \pm 2,1$, при середній тяжкості захворювання - 94,2 22,3 , а у найтяжчого контингенту $-113,3 \pm 2,5$. У останньої групи досліджуваних цей показник уночі виявився навіть вищим, аніж у осіб контрольної групи вдень.

Згідно з законами клінічної фізіології [4], загальний периферійний опір судин (ЗПОС) прямо пропорційний артеріальному тиску (середньому) та обернено - серцевому викиду.

Аналіз показників загального периферійного опору судин засвідчив, що в обстежених паці$\epsilon$ нтів уночі спостерігається чітка тенденція до його зростання. При показниках норми 12001400 дин $\cdot$ сек $^{-1} \cdot \mathrm{C}^{-1} \cdot \mathrm{CM}^{-5}$ в усіх пацієнтів уночі ЗПОС виявився підвищеним: як у осіб контрольної групи (на 6,4 \% понад верхнюю межу норми), так і у хворих досліджуваних груп (відповідно, на 6,4 \%, на $10,0 \%$ та на $11,5 \%)$

Отримані результати вказують на переважно судинний механізм формування у пацієнтів артеріальної гіпертензії. У осіб контрольної групи підвищення ЗПОС, очевидно, зумовлене віковими особливостями (ймовірно, проявами атеросклерозу).

Патофізіологічне обґрунтування феномену більш значного навантаження на серцево-судинну систему та підвищення периферійного опору судин у обстежуваних хворих у нічний час полягає у наступному. У хворих на синдром сонного апное спостерігається періодична зупинка дихання уві сні. Зумовлені цим епізоди гіпоксії та гіперкапнії $\epsilon$ стресом для організму, вони спричиняють активацію симпатичного відділу автономної нервової системи та викидання у кров її медіаторів, які під- 
Огляди літератури, оригінальні дослідження, погляд на проблему, випадок з практики, короткі повідомлення вищують тонус артеріол, сприяють підвищенню частоти серцевих скорочень та серцевого викиду.

Очевидно, що часті та тривалі порушення мікроциркуляції у цих випадках також зумовлюють у хворих в подальшому формування органних порушень [5].

Така багаторазова протягом ночі стимуляція роботи серця і підвищення тонусу артеріол з часом сприяють формуванню у пацієнтів гіпертонічної хвороби.

Висновки. 1. У хворих на синдром обструктивного апное-гіпопное сну у нічний час під час

епізодів апное-гіпопное синхронно тяжкості патології розвивається феномен активації серцевосудинної системи, який проявляється зростанням серцевого викиду, частоти серцевих скорочень та загального периферійного судинного опору.

Феномен активації серцево-судинної системи, який виникає під час багаторазових пробуджень під час сну у хворих на СОАГС, сприяє формуванню у них гіпертонічної хвороби, а зростання загального периферійного опору судин призводить до органних порушень (серцевої, ниркової недостатності, цукрового діабету тощо).

\section{ЛІТЕРАТУРА}

1. Синдром обструктивного апноэ/гипопноэ сна: критерии степени тяжести, патогенез, клинические проявления и методы диагностики / О. В. Алексеева, Н. А. Шнайдер, И. И. Демко, М. М. Петрова // Сибирский медицинский журнал (Иркутск). - 2016. - № 1.

2. Синдром обструктивного апное сну: зв'язок із серцево-судинними захворюваннями та основні методи діагностики / В. Г. Лизогуб, О. В. Савченко, Т. В. Завальська [та ін.] // Лікарська справа. Врачебное дело. 2012. - № 1/2. - C. 45-56.

\section{REFERENCES}

1. Alekseyeva, O.V., Shnayder, N.A., Demko, I.I., \& Petrova, M.M. (2016). Sindrom obstruktivnogo apnoe/ gipopnoe sna: kriterii stepeni tyazhesti, patogenez, klinicheskiye proyavleniya i metody diagnostiki [Obstructive sleep apnea/hypopnea syndrome: Severity criteria, pathogenesis, clinical manifestations and diagnostic methods]. Sibirskiy meditsinskiy zhurnal (Irkutsk) - Siberian Medical Journal (Irkutsk), 1 [in Russian].

2. Lyzohub, V.H., Savchenko, O.V., Zavalska, T.V., Dykukha I.S., \& Lozyuk M.O. (2012). Syndrom obstruktyvnoho apnoe snu: zviazok iz sertsevo-sudynnymy zakhvoriuvanniamy ta osnovni metody diahnostyky [Obstructive sleep apnea syndrome: connection with cardiovascular diseases and basic diagnostic methods]. Likarska sprava.

Vrachebnoe delo - Medical Business. Medical Business, 1/2, 45-56 [in Ukrainian].

3. Yermolayeva, T.N. (2014) Nochnoye apnoe u patsiyentov s arterialnoy gipertenziyey i metabolicheskim sindromom. Vliyaniye sipap-terapii [Sleep apnea in patients with arterial hypertension and metabolic syndrome. Influence of sipap therapy]. Arkhiv vnutrenney meditsiny - Archives of Internal Medicine, 3 (17), 60-66 [in Russian].

4. Mancia, G., Laurent, S., \& Gabiti-Rosei E. (2009) Reappraisal of European guidelines on hypertension management: a European Society of Hypertension Task Force document. J. Hypertens., 27, 2121-2158.

5. Doonan, R.J., Scheffler, P., \& Lalli, M. (2011) Increased arterial stiffness in obstructive sleep apnea: a systemic rewiew. Hypertens. Res., 34, 23-32. 
Огляди літератури, оригінальні дослідження, погляд на проблему, випадок з практики, короткі повідомлення

\title{
ОСОБЕННОСТИ ФУНКЦИОНИРОВАНИЯ СЕРДЕЧНО-СОСУДИСТОЙ СИСТЕМЫ У БОЛЬНЫХ СИНДРОМОМ ОБСТРУКТИВНОГО АПНОЭ-ГИПОПНОЭ В НОЧНОЕ ВРЕМЯ
}

๑Р. Е. Солтани

\author{
Тернопольский национальный медицинский университет имени И. Я. Горбачевского МОз Украины
}

РЕзЮМЕ. В статье приведены результаты исследований особенностей функционирования сердечно-сосудистой системы у больных синдромом обструктивного апноэ-гипопноэ сна.

Цель - оценить особенности функционирования сердечно-сосудистой системы у больных синдромом обструктивного апноэ - гипопноэ во время сна.

Материал и методы. Исследование проведено у 66 больных с диагностированным синдромом обструктивного апноэ-гипопноэ сна (СОАГС). Диагноз СОАГС устанавливали у пациентов, у которых в течение 1 часа сна происходило более 5 остановок дыхания длительностью 10 секунд и более (индекс апноэ-гипопноэ, ИАГ).

Результаты. Установлено, что в ночное время во время эпизодов апноэ-гипопноэ синхронно тяжести патологии развивается феномен активации сердечно-сосудистой системы, который проявляется ростом сердечного выброса, частоты сердечных сокращений и общего периферического сосудистого сопротивления. Во время сна коэффициент экономичности кровообращения (КЭК) у пациентов группы контроля снижался почти на $40 \%$ по сравнению с данными, полученными у них днем. Однако, по сравнению с группой контроля, ночью КЭК у больных 1-й группы оказался выше на 11,4%; у больных 2-й группы - на 8,0 \%; у больных 3-й группы - на 25,8 \%.

Выводы. Активация сердечно-сосудистой системы у больных СОАГС способствует формированию у них гипертонической болезни, а рост общего периферического сопротивления сосудов приводит к органным нарушениям (сердечной, почечной недостаточности, сахарному диабету и т. д.).

КЛЮЧЕВЫЕ СЛОВА: синдром обструктивного апноэ-гипопноэ сна; системная гемодинамика; сердечный выброс; общее периферическое сосудистое сопротивление; коэффициент экономичности кровообращения.

\section{THE PECULIARITIES OF CARDIOVASCULAR SYSTEM ACTIVITY IN PATIENTS WITH OBSTRUCTIVE APNE-HYPOPNEA SYNDROME AT NIGHT}

@R. E. Soltani

\section{Horbachevsky Ternopil National Medical University}

SUMMARY. The article presents the results of studies of the peculiarities of the cardiovascular system activity in patients with obstructive sleep apnea-hypopnea syndrome.

The aim - to evaluate the features of the cardiovascular system activity in patients with obstructive sleep apneahypopnea syndrome during sleep.

Material and Methods. The study was conducted in 66 patients diagnosed with obstructive sleep apnea-hypopnea syndrome (OSAHS). The diagnosis of OSAHS was established in patients who during 1 hour of sleep showed more than 5 respiratory stops lasting 10 seconds or more (apnea index - hypopnea, IAH).

Results. It was established that at night during episodes of apnea-hypopnea synchronously with the severity of the pathology, the phenomenon of activation of the cardiovascular system develops, which is manifested by an increase in cardiac output, heart rate and total peripheral vascular resistance. During sleep, the circulatory efficiency ratio (CER) in the patients of the control group decreased by almost $40 \%$, compared with the data obtained in them during the day. However, in comparison with the control group, at night CER in patients of group 1 was higher by $11.4 \%$; in patients of group 2 - by $8.0 \%$; in patients of group 3 - by $25.8 \%$.

Conclusions. Activation of the cardiovascular system in patients with OSAHS contributes to the formation of hypertension in them, and the growth of total peripheral vascular resistance leads to organ disorders (heart, kidney failure, diabetes, etc.).

KEY WORDS: obstructive sleep apnea-hypopnea syndrome; systemic hemodynamics; cardiac output; total peripheral vascular resistance; circulatory efficiency ratio. 